\title{
Changing The Ethical Standards Of Organizations
}

David F. Bean, (E-mail: dbean@iona.edu), Iona College Jill M. D’Aquila, Iona College

\begin{abstract}
The scandals of Enron and WorldCom appear to be contagious and are the impetus for the media's current focus on ethical issues. Business has been and continues to confront ethical dilemmas that impact decision-making and financial reporting. Codes of conduct and a focus on ethical standards continually surface as proposals to change the ethical values of organizations. Many argue that it is the "tone at the top" that is the driving force behind any serious changes to the ethical culture in organizations. This study presents the results of a survey of practicing CPAs. A factor analysis identifies the actions and procedures that are linked with a management culture that emphasizes the importance of integrity and ethical values. The results provide guidance on the key factors involved in invoking ethical change in organizations. These results should prove to be of assistance to both educators and employers in the development of feasible programs that maximize the ethical potential of organization members.
\end{abstract}

\section{INTRODUCTION}

$B$

usiness ethics continues to be a "hot" topic for the media, especially given the ethical lapses at organizations such as Enron and WorldCom, as well as the enactment of the Sarbanes-Oxley Act of 2002. In the past ethical transgressions/events were often buried in the back pages of news publications and typically not considered to be worthy of mention on the national airwaves. Today these items are front-page news and lead stories on national networks. In fact, the numerous ethical lapses and the resultant problems with the stock market were the impetus for the enactment of the Sarbanes-Oxley Act of 2002. The Act, which aims to restore public confidence in the financial markets, was developed based on the results of a series of hearing with numerous experts, former regulators, leading academics, and representatives from consumer and industry groups undertaken by the Senate Banking Committee, which overwhelmingly indicated weak corporate governance procedures, among other things.

This startling increase in attention has had both positive and negative impacts on business. In terms of negative consequences, some believe that business has been characterized as being populated by greedy and unscrupulous individuals whose mantra is "maximize profits and trivialize the consequences". In this view, the deforestation of the Amazon and workers dying from industrial pollution are of no consequence relative to the importance of the 'bottom line'. However, the spate of indignation and outrage associated with Enron and others has also had a positive impact because it has focused attention on business ethics and the creation of ethical organizations. Governments, organizations and individuals are increasingly concerned with ethical matters and the creation of a work environment that encourages ethical behavior.

Ethical dilemmas continue to confront the day-to-day issues and long-range strategic plans of organizations. Some believe that business has been proactive and they point to the plethora of codes of conducts and formal ethical standards as evidence of a good faith effort in dealing with these dilemmas. Others believe that such approaches are merely window dressing and not indicative of a serious campaign against unethical actions and behavior. At Enron, for instance, there was a code of conduct that employees signed. Furthermore, it was updated annually. Sherron Watkins, Former Vice President for Corporate Development of Enron, also known as the "whistleblower" who alerted the former $\mathrm{CEO}$ of Enron Corporate to accounting irregularities within the company, points out that an organization can have a wonderful anonymous employee hotline and a great value system on paper. However, the question is 
whether the company is getting the value system "from the walls to the halls when the great performers can violate the values at will and go unpunished." She points out that such a value system is meaningless. "How the leader models those values and standards sets the tone for what's acceptable behavior in the organization (Lucas and Koerwer, 2004)." Many others also argue that the "tone at the top" is the driving force behind any real substantive change to an organization's ethical climate

This study presents a survey of one hundred and ninety six practicing CPA's. The resulting factorial analysis identifies the actions and procedures that are linked to a management culture that emphasizes the importance of integrity and ethical values. The intent of the study is to assist both educators and employers in the development of feasible programs that maximize the ethical potential of organization members

\section{ETHICAL CULTURE}

The overwhelming initial reaction to attacks on the ethics and credibility of organizations was the creation of "codes of conduct". These codes often spell out the "dos and don'ts" of proper ethical behavior and vary considerably in their detailed instructions. The existence of a code of conduct is unarguably important. In fact, under the SarbanesOxley Act, the Securities and Exchange Commission (SEC) has adopted rules requiring all reporting companies to disclose whether the company has adopted a written code of conduct for senior management. Although not required to adopt such codes, companies that do not have codes must explain why not. The Sarbanes-Oxley Act also provides specific guidance in formulating such codes. For some organizations the code of conduct is a document that many organizational members try to live up to. However, codes of conduct have limitations in terms of their ability to address complicated and non-routine dilemmas. Furthermore, they are often framed as a negative enforcement process. Noncompliance may result in dismissal, criminal prosecution, etc. Modern management techniques suggest that more is needed.

Accountants and management are heavily reliant upon internal control systems to effectively carry out their day-to-day functions and responsibilities. The Committee of Sponsoring Organizations of the Treadway Commission (COSO, 1992) noted that "The effectiveness of internal controls cannot rise above the integrity and ethical values of the people who create, administer, and monitor them (p. 19)." Anecdotal evidence also offers insight into the issue of tone at the top. Excerpts from Abelson's 2000 interview are particularly revealing “. . .three former executives said today that for almost the entire history. . .its top executives directed a conspiracy to inflate profits. . .It was just ingrained in all of us, ingrained in us by our superiors, over a very long period of time. . .I just thought I was doing my job." Pervasive in the preceding and in the ethics/management literature is the notion that upper management is able to influence organizational culture. Not surprisingly, most researchers implicitly assume employees are influenced by management (Baumhardt, 1961; Ferrell and Gresham, 1985; Soutar et al., 1994; etc.). As Bill Donaldson, Chairman of the Securities and Exchange Commission, points out, "Successful corporate leaders must therefore strive to do the right thing, in disclosure, in governance, and otherwise in their business, and they must instill in the corporations this attitude of doing the right thing... They should make this approach part of their company's DNA." (Lucas, 2004). Research consistently demonstrates that the ethical philosophies and values of management significantly impact the behavior of organization members (D'Aquila, 1998; Stead et al., 1990; Soutar et al., 1994; Wimbush and Shephard, 1994). The "do as I say, not as I do" philosophy does not hold up well in the business environment nor in most organizational settings. Managers set the tone by what they do, as actions do speak louder than words. If management desires an ethical culture then they must become active advocates for this value system and they must communicate consistent and appropriate messages both in words and in deeds (Dobni et al., 2000). The importance of this process cannot be overemphasized as the creation of organizational values by management and others creates a unifying theme that provides meaning and direction for organizational members (James et al., 1990). This is a powerful operational strategy as organizational values function as tools of social control that normally approves, constrains or prohibits behaviors of organizational members (O'Reilly, 1989). Organizational values give direction to the myriad of decisions made at all levels of the organization every day (Schmidt and Posner, 1983)and,thus enable members to operate in a more efficient and effective manner. 


\section{RESEARCH QUESTIONS}

The literature on "tone at the top" addresses many aspects of this behavioral modifier. However, two recurring themes appear to be present in most studies and discussions: (1) There should be a clear communication of the importance of ethical behavior and this position should be supported through words and actions (e.g. Minkes et al., 1999). (2) Communication of values has integrity only if the behavior of upper management is consistent with the communicated organizational values (e.g. McDonald, 2000).

Given the significance of an organizational culture that fosters ethical values, it is helpful to more fully understand the ways in which organizations communicate these values. Furthermore, if organizations aim to promote ethics in the workplace, it is also helpful to clearly understand employee perceptions of the organizational culture. Therefore, the present study was conducted to address the following research questions:

1. Are there distinct ways in which organizations communicate the importance of ethical standards?

2. If so, to what degree do CPAs believe their organizations emphasize the importance of integrity and ethical values in these ways?

\section{METHOD}

A description of the sample, the procedures for collecting the data, and a description of the instruments are presented in this section.

\section{Sample and Data Collection Procedures}

A survey instrument was used to obtain anonymous information about CPAs perceptions of the degree to which their organizations foster ethical standards. The sample consisted of 400 CPAs who perform financial reporting randomly selected from an AICPA membership roster. These CPAs were mailed a packet containing the survey, a stamped self-addressed envelope, and a postcard. The subjects were requested to return the postcard separately from the completed questionnaire to identify responses and maintain anonymity. Two follow-up requests were mailed to the subjects who did not return their initial postcard. A total of 196 responses (50\%) were received and a total of five questionnaires were undeliverable. Respondents were controllers (44.7\%), CFOs/CEOs/Presidents (27.7\%), supervisors $(16.0 \%)$, staff accountants $(4.2 \%)$, and accountants in other positions (7.4\%).

\section{Data Collection Instrument}

Information describing employee perceptions of their organization's overall culture was obtained using fourteen questions from a more comprehensive instrument developed by the researchers based on guidelines established by COSO (1992). The questionnaire was designed to obtain information as part of a broader research program about the control environment. Subjects in this study were asked to circle one of five rank ordered answer choices. The choices reflected the subject's perception of their organization's emphasis on integrity and ethical values.

\section{Data Analysis and Results}

A factor analysis of the results from the questionnaire was performed to determine if there are any underlying dimensions. As disclosed in Table I, the factor analysis indicates that the fourteen questions measure the following three factors that, together, explain $69 \%$ of the variance in the data:

1. management's behavior and expectations;

2. actions relating to misconduct;

3. guidance provided by organizations. 
Table 1: Factor Analysis

\begin{tabular}{|c|c|c|c|}
\hline Control Environment Questions & $\begin{array}{l}\text { Managemen's Behavior/ } \\
\text { Expectations } \\
\end{array}$ & Misconduct & Guidance \\
\hline $\begin{array}{l}\text { Does (or would) management ever compromise ethical } \\
\text { standards to achieve a business goal? }\end{array}$ & .863 & & \\
\hline $\begin{array}{l}\text { Does management ever expect you to compromise ethical } \\
\text { standards to achieve a business objective? }\end{array}$ & .848 & & \\
\hline $\begin{array}{l}\text { Does management pay attention to ethical issues when } \\
\text { dealing with others? }\end{array}$ & .768 & & \\
\hline $\begin{array}{l}\text { Does (or would) management ever override established } \\
\text { controls? }\end{array}$ & .683 & & \\
\hline $\begin{array}{l}\text { Do the individuals to whom you report reinforce } \\
\text { management's expectations of ethical standards? }\end{array}$ & .559 & & \\
\hline $\begin{array}{l}\text { Does (or would) management investigate deviations from } \\
\text { established policies? }\end{array}$ & & .902 & \\
\hline $\begin{array}{l}\text { Does management encourage you to report attempts by others } \\
\text { to override established controls? }\end{array}$ & & .634 & \\
\hline $\begin{array}{l}\text { Does (or would) management investigate complaints of } \\
\text { alleged misconduct? }\end{array}$ & & .558 & \\
\hline $\begin{array}{l}\text { Does (or would) management deal with wrongdoings in a } \\
\text { manner commensurate with the wrongdoing? }\end{array}$ & - & .535 & \\
\hline Will you be disciplined if you violate a behavioral standard? & & .531 & \\
\hline $\begin{array}{l}\text { To what extent does your organization have a code of conduct } \\
\text { or other policies that addresses important issues regarding } \\
\text { acceptable business practices? }\end{array}$ & & & .798 \\
\hline $\begin{array}{l}\text { Does your organization provide guidance about what you } \\
\text { should do if you encounter unethical behavior? }\end{array}$ & & & .760 \\
\hline Is it clear what behavior is acceptable? & & & .659 \\
\hline $\begin{array}{l}\text { Does management verbally communicate expectations of high } \\
\text { ethical standards? }\end{array}$ & & & .600 \\
\hline
\end{tabular}

The Alpha Cronbach Coefficient was then calculated for these three variables to determine the reliability of each factor scale. Coefficient scores of .89, .84, and .81 for each of the variables, respectively, indicate strong reliability of each factor score. These scores are disclosed in Table II.

Table 2: Mean, Range, Standard Deviation, And Alpha Cronbach Coefficient

\begin{tabular}{|l|c|c|c|c|}
\hline Factor & Mean & Range & Standard Deviation & Alpha Cronbach Coefficient \\
\hline $\begin{array}{l}\text { Management's Behavior/ } \\
\text { Expectations }\end{array}$ & 4.00 & $1-5$ & .818 & .89 \\
\hline Misconduct & 3.99 & $1-5$ & .725 & .84 \\
\hline Guidance & 3.35 & $1-5$ & .966 & .81 \\
\hline
\end{tabular}

Total scores for each of the three factors was then determined by 1) weighting each individual question according to its relative factor score, as disclosed in Table I, and 2) adding the resultant score for each individual question comprising the factor (five questions for management's behavior/expectations and for misconduct, and four questions for guidance). Since relative weights were used, all factors range from 1-5 points (the point values of the likert scale). Using the same ranges for each factor facilitates the analysis. Descriptive data, including mean scores, ranges, and standard deviations, are disclosed in Table II. All three mean scores (4.00, 3.99, and 3.35 respectively) fall above the mid point of the range. 
Correlation coefficients were calculated to determine whether these factors relate to the degree to which CPAs believe their organizations emphasize the importance of integrity and ethical values. Correlation scores of .721, .687 , and .736 indicate that all three correlations coefficients are strong and are significant at $p<.01$. Correlations also indicate interrelationships between all three factors.

\section{Table 3: Correlation Coefficients}

\begin{tabular}{l|c|c|c|}
\hline \multicolumn{1}{|c|}{ Factor } & Management Culture $^{(\mathbf{a})}$ & $\mathbf{1}$ & $\mathbf{2}$ \\
\hline 1 & $.721^{*}$ & & \\
\hline 2 & $.687^{*}$ & $.705^{* * *}$ & $.642^{* * *}$ \\
\hline 3 & $.736^{*}$ & $.607^{* * *}$ & \\
\hline \multirow{2}{*}{$\begin{array}{l} \\
\text { 1. } \quad \text { Management's Behavior/Expectations }\end{array}$} \\
2. Misconduct \\
3. Guidance
\end{tabular}

\section{DISCUSSION}

The analysis indicates that three distinct factors emerge from the organizational culture which relate to an organization's focus on ethical standards: 1) management's own behavior and expectations; 2) actions that relate to misconduct; and 3) guidance. Overall, CPAs believe their organizations foster ethical standards through all three factors identified by the factor analysis. However, as suggested by the differing mean values reported in Table II, the degree to which the organizations foster ethical standards is not equally strong across all three factors. Overall, CPAs believe that a focus on ethical standards is more pronounced in management's own behavior/expectations and in actions relating to misconduct, as opposed to guidance provided by organizations. Although there is a somewhat more than moderate amount of guidance being offered by organizations, CPAs believe that the focus on ethical standards rings resoundingly in the daily actions of management. In the end, actions do speak louder than words.

Despite all the measures taken by an organization to promote strong ethical standards, the most important aspect is whether employees believe that the management culture emphasizes the importance of integrity and ethical values. In other words, are all three factors identified in this study important in fostering an ethical climate? The correlation coefficients indicate that the answer is yes. Management's behavior/expectations, actions that relate to misconduct, and guidance provided by organizations all strongly and fairly equally contribute to an employee's belief about the organization's culture. Furthermore, the interrelationships between these factors indicate that managers who act ethically and expect their employees to do so (factor 1) are likely to appropriately deal with misconduct (factor 2) and to provide guidance to their employees (factor 3).

This study makes an important contribution by clearly delineating the distinct actions and procedures that are linked with a management culture that emphasizes the importance of integrity and ethical values. The results provide unequivocal evidence that the building/creation of an ethical organization is a complex and multifaceted process. Although the initial focus on codes of conduct was helpful, this research demonstrates the need for more sophisticated approaches and analyses. Research results and theoretical developments continue to impact the evolutionary processes inherent in the creation of ethical organizations. This study should be of assistance to both employers and educators in the development of feasible programs that maximize the ethical potential of organization members.

\footnotetext{
(a) The degree to which CPAs believe the management culture in their organizations emphasizes the importance of integrity and ethical values?
} 


\section{REFERENCES}

1. $\quad$ Abelson, R. (2000). The Road to Reviving a Reputation, New York Times, June 15, pp. C1 and C8.

2. Baumhardt, R. C. (1961). How Ethical are Businessmen?, Harvard Business Review, 39 (4), 7-176.

3. COSO - Committee of Sponsoring Organizations of the Treadway Commission (1992). Internal Control Integrated Framework.

4. D'Aquila, J. (1998). Is the Control Environment Related to Financial Reporting Decisions?, Managerial Auditing Journal, 13 (8), 472-478.

5. Dobni, D., J. R. Brent Ritchie, and W. Zerbe (2000). Organizational Values: The Inside View of Service Productivity, Journal of Business Research, 47, 91-107.

6. Ferrell, O. C. and L. G. Gresham (1985). A Contingency Framework for Understanding Ethical Decision Making in Marketing, Journal of Marketing, 55-64.

7. James, L. R., L. A. James, and D. K. Aske (1990). The Meaning of Organizations: The Role of Cognition and Values in Organizational Climate and Cultur, B. Schneider editor, Jossey-Bass, San Francisco, 40-84.

8. Lucas, N. (2004). An Interview with United States Senator Paul S. Sarbanes Journal of Leadership and Organizational Studies, 11, 3-8.

9. _ _ and V.S. Koerwer. (2004). Features Interview Sherron Watkins, Former Vice President for Corporate Development of Enron. Journal of Leadership and Organizational Studies, 11, 38-47.

10. McDonald, G. (2000). Business Ethics Practical Proposals for Organizations. Journal of Business Ethics, 25, 169-184.

11. Minkes, A. L., M. W. Small, and S. R. Chatterjee (1999). Leadership and Business Ethics: Does it Matter? Implications for Management, Journal of Business Ethics, 20, 327-335.

12. O'Reilly, C. (1989). Corporations, Culture and Commitment: Motivation and Social Control in Organizations, California Management Review, (summer), 9-25.

13. Sarbanes-Oxley Act (Public Law 107-204). 2002.

14. Schmidt, W. H. and B. Z. Posner (1983). Managerial Values in Perspective. American Management Association, New York.

15. Soutar, G., M. M. McNeil, and C. Molster (1994). The Impact of the Work Environment on Ethical Decision Making: Some Australian Evidence, Journal of Business Ethics, 13, 63-69.

16. Stead, W. E., D. L. Worrell, and J. G. Stead (1990). An Integrative Model for Understanding and Managing Ethical Behavior in Business Organizations, Journal of Business Ethics, 13, 63-69.

17. Wimbush, J. C. and J. M. Shephard (1994). Toward an Understanding of Ethical Climate: It's Relationship to Ethical Behavior and Supervisory Influence, Journal of Business Ethics, 13, 637-647. 